\title{
Artigos
}

\section{A LEI PELÉ, O FIM dO PASSE E A MODERNIZAÇÃO CONSERVADORA DO FUTEBOL-NEGÓCIO NO BRASIL: UMA ANÁLISE DAS PERCEPÇÕES DOS JOGADORES}

\section{LAW PELÉ, THE END OF THE PASS AND THE CONSERVATIVE MODERNIZATION OF THE SOCCER BUSINESS IN BRAZIL: AN ANALYSIS OF THE PERCEPTIONS OF THE PLAYERS}

\author{
Francisco Xavier Freire Rodrigues \\ Professor da Universidade Federal de Mato Grosso \\ Departamento de Ciência Política
}

\begin{abstract}
RESUMO
Este artigo analisa a concepção dos jogadores sobre os impactos da Lei Pelé no mercado futebolístico nacional. Investiga o processo de modernização conservadora do futebol-negócio no Brasil. A percepção predominante dos atletas é de que a Lei Pelé modernizou somente alguns elementos do futebol brasileiro. O fim do passe representou a passagem de um modelo tradicional de relações de trabalho para um modelo moderno e flexível, pois decretou a liberdade de trabalho para os jogadores e flexibilizou os contratos e relações de trabalho. A maioria dos jogadores considera que as principais intenções da Lei Pelé eram modernizar as relações entre clubes e jogadores. Os setores mais beneficiados pelo fim do passe, segundo a avaliação dos entrevistados, foram os jogadores, os empresários, o futebol como um todo e os clubes de futebol. O fim do passe tem influenciado no rejuvenescimento da força de trabalho no futebol brasileiro.
\end{abstract}

Palavras-chave: Lei Pelé; Modernização Conservadora; Futebol-Negócio; Fim do Passe.

\begin{abstract}
This article analyzes the players conception on the impacts of the Law Pele in the national football market. It investigates the conservative modernization process of the soccer business in Brazil. The predominant perception of the athletes is that the Law Pelé only modernized some elements of our soccer. The end of the pass represented the transition of a traditional model of work relations for a modern and flexible model, therefore it decreed the freedom of work for the players and flexibilized contracts and relations of work. The majority of the players considers that the main intentions of the Law Pelé were to modernize the relations between clubs and players. The players, the entrepreneurs, the soccer clubs and the soccer as a whole are the sectors which have been more benefited by the end of the pass, according to evaluation of the interviewed ones. The end of the pass has influenced promoting the young workforce in the Brazilian soccer.
\end{abstract}

Key-words: Law Pelé; Conservative Modernization; soccer business; End of the Pass. 


\section{INTRODUÇÃO}

O presente trabalho tem como tema a Lei Pelé ( $n^{\text {o }}$ 9.615/98), o fim do passe e a modernização conservadora no futebol brasileiro. O nosso objeto de investigação consiste nos impactos provocados pelo fim do passe no futebol-negócio brasileiro no período de 2001 a 2006, buscando apreender as características da modernização conservadora na sociedade brasileira mediante a análise da nova regulamentação das relações entre clubes e jogadores que entrou em vigor com a Lei Pelé, a partir das percepções dos atletas entrevistados. Tem como recorte empírico 12 clubes de futebol das séries A, B e C do campeonato brasileiro. Analisa-se o novo sistema de transferências de jogadores de futebol que surgiu com a Lei Pelé ( $n^{\circ}$ 9.615/98), os processos de modernização e a flexibilização das relações de trabalho no futebol brasileiro, na visão dos jogadores entrevistados.

A pesquisa ${ }^{1}$ que fundamenta o presente artigo se utilizou de técnicas quantitativas e qualitativas, predominando a perspectiva quantitativa. Elegemos a pesquisa quanti-qualitativa por meio da combinação de pesquisas bibliográfica, documental e de campo (questionários) (TRIVIÑOS, 1987), utilizando-se de dados estatísticos (frequência) obtidos a partir da utilização do programa SPSS.

A pesquisa qualitativa visa abordar o "mundo lá fora", entender, descrever e explicar os fenômenos sociais de diversas maneiras. Segundo Uwe Flick (2009, p. 8), a investigação qualitativa analisa experiências de indivíduos ou grupos, relacionadas a histórias biográficas ou a práticas profissionais e cotidianas, etc. Examina também interações e comunicações envolvendo os indivíduos. A referida pesquisa centra-se na compreensão e explicação da dinâmica das relações sociais (MINAYO, 2001).

A pesquisa quantitativa, segundo Richardson (1989), caracteriza-se pelo emprego da quantificação, tanto nas modalidades de coleta de informações, quanto no tratamento dessas através de técnicas estatísticas, desde as mais simples até as mais complexas. Este tipo de investigação possui como diferencial a intenção de garantir a precisão dos trabalhos realizados, conduzindo a um resultando com poucas chances de distorções.

\footnotetext{
${ }^{1}$ É importante informar o leitor que se trata da pesquisa realizada no período de 2004 a 2006 que deu origem a nossa tese de doutoramento intitulada $O$ fim do passe e a modernização conservadora no futebol brasileiro (2001-2006). Ver RODRIGUES, F. X. F. O fim do passe e a modernização conservadora no futebol brasileiro (2001-2006). 2007. Tese (Doutorado em Sociologia) - PPGS/UFRGS, Porto Alegre, 2007.
} 


\section{A Lei Pelé, o fim do passe e a modernização conservadora do futebol-negócio no Brasil: uma análise das percepções dos jogadores}

A coleta de dados se deu a partir da aplicação de questionários aos atletas profissionais do futebol brasileiro. O questionário constitui hoje uma das mais importantes técnicas disponíveis para a obtenção de dados nas pesquisas sociais. Entretanto, em virtude de haver vários termos que são frequentemente utilizados como sinônimos, o termo questionário aparece muitas vezes imerso em certa imprecisão. Assim, é comum falar-se em entrevista, formulário, teste, enquête e escala com sentido próprio ao de questionário. Pode-se definir questionário como a técnica de investigação composta por um número mais ou menos elevado de questões apresentadas por escrito às pessoas, tendo por objetivo o conhecimento de opiniões, crenças, sentimentos, interesses, expectativas, situações vivenciadas etc. (GIL, 1987, pp. 124-132).

Consultamos documentos oficiais da Confederação Brasileira de Futebol (CBF), da Federação Gaúcha de Futebol, dos Sindicatos dos Atletas Profissionais dos Estados de São Paulo e Rio Grande do Sul, da Justiça do Trabalho - RS, além dos dados da imprensa falada e escrita, contendo informações a respeito de contratos de jogadores, escolinhas de futebol, número de atletas formados no período determinado pela pesquisa e de atletas transferidos para outros clubes brasileiros e/ou estrangeiros.

Foram aplicados 97 questionários aos jogadores de futebol, distribuídos entre os clubes da seguinte forma: SC Internacional (06), Grêmio de Futebol Porto-Alegrense (11), Esporte Clube Juventude (05), Caxias (13), Glória de Vacaria (08), Fortaleza Esporte Clube (10), Fluminense Football Club (11), Paysandu-PA (04), Associação Atlética Ponte Preta (08), Cruzeiro Esporte Clube (10), Coritiba Foot Ball Club (07) e Clube de Regatas Vasco da Gama (04).

O passe surgiu com o Decreto $\mathrm{n}^{\circ} 53.820 / 64$, foi regulamentado pelo artigo 11 da Lei $n^{\circ} 6.354 / 76$ e legalmente extinto a partir de 25 de março de 2001, conforme o artigo 96 da Lei $n^{\circ}$ 9.615/98 (NAPIER, 2003, p. 260). O passe², vínculo desportivo do atleta com a entidade desportiva contratante, passa a ter natureza acessória ao vínculo empregatício, dissolvendo-se quando o contrato de trabalho chega ao seu final.

O artigo 28 da Lei Pelé ( $n^{\circ}$ 9.615/98) afirma que o atleta profissional do futebol, empregado em uma entidade desportiva, deve ter seu contrato regido pela legislação trabalhista (CLT, art. $3^{\circ}$ ). Ao ser extinto o passe, com a promulgação da referida lei se considera que acabou a prisão de um atleta profissional a uma entidade desportiva

\footnotetext{
2“O passe é o nome dado à formalidade de uma obrigação entre o atleta e uma entidade desportiva” (NAPIER, 2003, p. 244).
} 


\section{NORUS - v1, n.2, jan- jun 2014.}

empregadora. Com o passe em vigor, mesmo após o término do contrato de trabalho, o atleta continuava vinculado, aprisionado ao clube, não podendo se transferir para um outro clube de futebol, o que em outras palavras significa a ausência de liberdade de trabalho para o jogador, o mesmo não podia escolher outro empregador, ou seja, outro clube onde poderia praticar sua profissão. É importante salientar que

Com o instituto do passe, o atleta tornava-se um trabalhador que não tinha o direito de mudar de emprego, que não podia discutir bilateralmente seu contrato de trabalho, que se via obrigado a aceitar as condições impostas por seu empregador, sob pena de não poder exercer a sua profissão (NAPIER, 2003, p. 57).

Entende-se por "passe" a importância devida por um empregador a outro, equivalente à cessão do atleta durante a validade do contrato ou depois de seu término, dentro das normas desportivas. O passe seria, portanto, um mecanismo legal regulamentado pela Lei $\mathrm{n}^{\circ}$ 6.354/02/9/76, para regular a profissão de jogador de futebol. Pode-se dizer que o passe funcionava como uma espécie de licença e permissão que o jogador de futebol recebia para continuar trabalhando em outro clube, concedida pelos seus empresários e procuradores para que pudesse ser transferido ou negociado de um clube para outro, em troca de indenizações ou, até mesmo de outros jogadores (NAPIER, 2003, p. 55). Logo, o jogador de futebol era um trabalhador legalmente proibido de procurar emprego em outro clube, ou seja, impedido de escolher e decidir em que clube trabalhar. Na Lei $n^{\circ}$ 6.354/1976, a norma que dispôs sobre o esporte de forma mais ampla até o advento da Lei Pelé (Lei no 9.615/98), pode-se perceber uma definição de passe que não se sustenta sem os mecanismos de cessão e transferência do atleta, os quais tinham como intuito dar lucro aos empregadores (clubes de futebol). É um sistema que tinha como único objetivo a remuneração do clube que detinha a propriedade do atleta. Esta Lei vinculava o atleta ao clube, ao qual ficava preso, mesmo depois de terminado o contrato de trabalho, inclusive sem receber salário (RODRIGUES, 2007).

O passe era seria talvez o mecanismo mais atrasado do direito do trabalho brasileiro. $\mathrm{O}$ regime híbrido proposto pela Lei Pelé, que estabeleceu o fim do passe, mesmo sendo muito mais avançado que a lei do passe, não colocou ainda o jogador de futebol em condições de se igualar com o trabalhador urbano ${ }^{3}$. Devem-se ressaltar ainda fatores como a jornada de trabalho e o calendário esportivo exaustivo que predominam no futebol, a indiferença das ocorrências de acidentes e doenças do trabalho, a vida útil laboral curta, a imposição de horários e trabalho

\footnotetext{
${ }^{3} \mathrm{O}$ trabalhador rural em muitos casos ainda mantém condições de desvantagens em relação ao urbano.
} 


\section{A Lei Pelé, o fim do passe e a modernização conservadora do futebol-negócio no Brasil: uma análise das percepções dos jogadores}

por contratos comerciais dos clubes, além disso, a péssima remuneração da grande maioria dos jogadores. A Lei Pelé regulamenta a cláusula penal que "é uma multa contratual para as hipóteses de descumprimento, rompimento ou rescisão unilateral de todos os contratos de atletas profissionais de todas as modalidades desportivas" (Art. 28, Lei n ${ }^{\circ}$ 9.615/98).

Percebemos que a cláusula penal tem sido utilizada como mecanismo para prender o jogador profissional ao clube na nova configuração do mercado de trabalho, no futebol brasileiro, pós-Lei Pelé. Álvaro Mello Filho defende a unilateralidade da cláusula penal. Segundo ele, a cláusula penal seria devida pelo atleta ao clube, resultado do rompimento unilateral por vontade do atleta; teria natureza compensatória pela quebra do pacto de permanência; a responsabilidade por seu pagamento seria transferida, por costume, ao clube adquirente ou ao clube de destino do atleta e seu valor seria fixado pelas partes contratantes e submetido a redutores estatuídos na lei (MELLO FILHO, 2000, p. 127). Tudo isso constituiu fatores que merecem ser revisados, pois fazem com que o profissional do futebol tenha uma situação de trabalho peculiar.

O passe sempre se constituiu no grande suporte financeiro dos clubes de futebol do Brasil, aquele fazia com que o clube que possuísse o vínculo com o atleta pudesse exigir do clube interessado neste, uma importância para que este pudesse usufruir dos serviços do atleta. Com a Lei n 9.615/98 e suas modificações, em 26/03/2001, o "arcaico" instituto do passe deixou de existir. Sua extinção foi decretada pelo art. $2^{\circ}$ da referida lei, sendo fruto de um esforço conjunto do governo brasileiro e das entidades ligadas ao esporte que, motivadas pelo acordo firmado entre a FIFA ${ }^{4}$ e a UEFA ${ }^{5}$, decidiram extingui-lo. Este teria sido o marco inicial da reestruturação desse esporte no Brasil (MACIEL 2003, p. 53).

A lei que continha o fim do passe ainda possibilitou, como forma de compensação financeira ao clube formador do atleta, o direito de assinar o primeiro contrato profissional com o mesmo, assim consta no "Art. 29 - A entidade de prática desportiva formadora de atleta terá o direito de assinar com este, a partir de dezesseis anos de idade, o primeiro contrato de trabalho profissional, cujo prazo não poderá ser superior a cinco anos" (Lei $\left.{ }^{\circ} 10.672 / 03\right)$. O contrato de trabalho do atleta profissional teria prazo determinado, com vigência nunca inferior a três meses, nem superior a cinco anos.

A entidade formadora ainda teria preferência pela primeira renovação de contrato do jogador. Esta entidade, e somente esta, teria direito a exigir um tipo de indenização por ter

\footnotetext{
4 Federação Internacional de Futebol.

${ }^{5}$ União das Federações Europeias de Futebol.
} 


\section{NORUS - v1, n.2, jan- jun 2014.}

contribuído na formação do jogador da entidade compradora do atleta. Essa indenização, muitas vezes funciona como o antigo passe, pois torn o atleta objeto de troca no mercado, ou seja, uma mercadoria.

O fim do passe foi resultado de um conjunto de mudanças na legislação e na estrutura administrativa do futebol, que teve início com a criação do Clube dos Treze, em 1987, consolidando-se com a promulgação da Lei Pelé, e mais especificamente com o artigo que estabelece liberdade de trabalho ao jogador de futebol.

A flexibilização das relações de trabalho no futebol expressar-se-ia no fim do passe. Para sua análise, antes são necessárias algumas notas gerais acerca do processo de alteração no mundo do trabalho contemporâneo. Destaca-se aqui o conceito de flexibilidade: "Por flexibilidad en general se entiende una adaptación de las relaciones laborales a las transformaciones provenientes del entorno económico y político en que se dan estas relaciones" (SUPERVIELLE \& QUIÑONOES, 2000, p. 20).

O processo de flexibilização do trabalho precisa ser especificado para garantir um debate mais profundo. Assim, pode-se dizer que, mesmo sendo de uso genérico, o termo flexibilização

[...] consiste em uma estratégia gerencial, tendo em vista elevar o grau de adaptação aos novos parâmetros técnicos e econômicos, indicando a substituição de uma solução uniforme, por uma série de soluções alternativas. A flexibilização apresenta-se sob diferentes modalidades: entre outras formas, pode-se destacar a flexibilidade temporal (refere-se à duração do tempo de trabalho ou à distribuição do tempo de trabalho no dia, semana, mês, ano ou ciclo de vida); flexibilidade produtiva (refere-se à diversificação da produção tendo em vista proteger as empresas dos problemas decorrentes de flutuações conjunturais); flexibilidade organizacional (externa, quando subcontratação de fornecedores; interna, quando envolve mudanças no processo de trabalho, como, por exemplo, a introdução do trabalho em equipe) (LARANJEIRA, 1997, p. 43).

Este artigo tem por objetivo fazer uma análise da concepção dos jogadores brasileiros sobre os impactos da Lei Pelé e do fim do passe para o mercado futebolístico nacional. Nosso foco é o entendimento dos atletas brasileiros acerca dos efeitos provocados pela nova legislação sobre a modernização do futebol. O artigo divide-se nas seguintes partes: (1) Introdução; (2) A Lei Pelé e a modernização do futebol brasileiro: as percepções dos jogadores entrevistados; (3) Análise da percepção dos atletas entrevistados sobre o fim do passe como uma transição de um sistema tradicional de transferências de jogadores para um sistema moderno e flexível; (4) Apresentação das concepções dos jogadores entrevistados 


\title{
A Lei Pelé, o fim do passe e a modernização conservadora do futebol-negócio no Brasil: uma análise das percepções dos jogadores
}

sobre as principais intenções da Lei Pelé; (5) Avaliação dos jogadores sobre os impactos/efeitos mais importantes do fim do passe no futebol brasileiro; (6) Análise da opinião dos jogadores entrevistados sobre os setores (e atores) mais favorecidos pelo fim do passe; (7) Apresentação da percepção dos atletas entrevistados sobre profissionalização precoce de jogadores e rejuvenescimento da força de trabalho no futebol brasileiro; (8) Finalmente, as considerações finais e as Referências.

\section{A LEI PELÉ E A MODERNIZAÇÃO DO FUTEBOL BRASILEIRO: AS PERCEPÇÕES DOS JOGADORES ENTREVISTADOS}

A recente transformação (e/ou reestruturação) do mercado futebolístico brasileiro pode ser relacionada diretamente a uma nova fase de desenvolvimento da modalidade, na qual predomina o futebol-empresa. Nessa atual fase, também compreendida como parte da "era da globalização", a produção e a veiculação do espetáculo futebolístico ganharam grande impulso nos principais centros futebolísticos mundiais (PRONI, 2001).

É necessário definirmos o que se entende por globalização, assim, para Carlos Estevam Martins (1996, pp.1-2):

\begin{abstract}
Simplificadamente, a globalização pode ser entendida como o resultado da multiplicação e da intensificação das relações que se estabelecem entre os agentes econômicos situados nos mais diferentes pontos do espaço mundial. Em outras palavras, trata-se de um processo que, para avançar, requer a abertura dos mercados nacionais e, tanto quanto possível, a supressão das fronteiras que separam os países uns dos outros. O motor que impulsiona a globalização para diante é a competição, juntamente com tudo aquilo que ela exige como condições de sua realização integral, vale dizer, competição irrestrita (livre dos entraves que a possam cercear) e universal (envolvendo todos contra todos em qualquer ponto do planeta). Global e globalização são termos que não devem ser confundidos com internacional $\mathrm{e}$ internacionalização. Global e globalização não se referem a relações entre nações, mas a forças supranacionais que, sem ter compromissos maiores com suas bases territoriais de origem, condicionam por toda a parte $\mathrm{o}$ funcionamento das sociedades nacionais. [...] Com a globalização, os investidores, estejam onde estiverem, ficam assegurados de que estão sendo tomadas providências (liberalizadoras, desregulamentadoras, privatizadoras e terceirizadoras) para abolir os obstáculos que por ventura impeçam a realização de suas atividades onde quer que se torne possível obter lucros.
\end{abstract}

A mudança estrutural que ocorre no futebol, caracterizada pela introdução de novas formas de gestão, pela interface com o capital financeiro, pelas mudanças na legislação 


\section{NORUS - v1, n.2, jan- jun 2014.}

esportiva e, sobretudo, pela transformação do futebol em produto globalmente comercializado tem uma evolução própria em cada país, tendo diferentes significados.

Partindo da história recente do Brasil, vimos que ao longo do século XX, se tornaram evidentes e, de certa forma, frequentes uma certa percepção do "atraso" do futebol brasileiro e também as tentativas de modernizar a sociedade brasileira, sendo o "moderno" identificado com o que vem de fora, ou seja, com o que é importado. No entanto, o mais problemático é que

[...] com frequência, adentrava-se na tal modernidade de modo parcial, restrito. Mantinham-se as raízes, a estrutura arcaica de poder, sobrepondose a ela uma roupagem nova, um invólucro de modernidade. Analogamente, a evolução da organização e da configuração institucional da modalidade esportiva mais visada e comentada do país acabou expressando esse mesmo traço constitutivo da nossa sociedade. Inclusive, nos anos noventa, a modernização da gestão econômica avançou na frente, em descompasso com a modernização da estrutura política - descompasso este que parece ter-se tornado emblemático do nosso desenvolvimento tardio (PRONI, 2001, p. 3).

As transformações pelas quais passa o futebol brasileiro nos permitem uma análise baseada na argumentação acima. Sabemos que o futebol profissional foi visto em diferentes momentos como uma construção inacabada. Todo o discurso modernizante apontava para um projeto incompleto. Identificava-se o modelo futebolístico europeu o melhor a ser seguido, ou seja, como a referência de modernidade.

Conforme destaca Proni (2001, p. 04),

A força da modernidade está justamente no seu significado progressista (ao exigir um mercado de trabalho livre, por exemplo). Não obstante, é preciso examinar o conteúdo do "progresso", analisar a quem cabem as escolhas. Talvez não seja socialmente benéfico, ou desejável, trocar a ética do esporte associativo pela ética da maximização dos lucros. Em particular quando a lógica do mercado conduz à exclusão e à ampliação das desigualdades, que são tendências desarticuladoras dos princípios (liberdade, igualdade e fraternidade) que deveriam embasar a construção da modernidade.

A análise que estamos fazendo dessa mudança insere-se em uma perspectiva econômica aberta pela expansão da indústria do entretenimento e do marketing esportivo, bem como no aspecto da revisão da legislação esportiva.

Nossas pesquisas acerca do processo de modernização do futebol brasileiro por meio da nova legislação (RODRIGUES, 2007) indicam que a Lei Pelé (n 9.615/1998) teria criado 


\section{A Lei Pelé, o fim do passe e a modernização conservadora do futebol-negócio no Brasil: uma análise das percepções dos jogadores}

as bases legais e institucionais para a modernização do futebol no Brasil, mas não teria completado tal processo, principalmente, devido às alterações sofridas em decorrência das emendas propostas e impostas pelos parlamentares defensores dos interesses dos clubes e dos dirigentes no congresso nacional (Lei Maguito Vilela, $n^{\circ}$ 9.981/2000).

A Lei Pelé se insere no movimento de modernização do esporte buscando dar uma nova dimensão jurídica ao futebol brasileiro. Buscamos captar a percepção dos jogadores sobre a lei Pelé e seus impactos no futebol brasileiro. A nossa hipótese é de que a referida Lei modernizou somente alguns aspectos do futebol brasileiro, o que sugere ser uma modernização conservadora na perspectiva utilizada por Fernandes (1976) para entender a modernização da sociedade brasileira. Uma análise profunda indica que a Lei Pelé modernizou um conjunto de fatores do nosso futebol, sendo mais atuante no conjunto das relações de trabalho e no processo de empresariamento do futebol.

As investigações realizadas para fundamentar nossa argumentação nos levam a reconhecer que a Lei Pelé e o fim do passe trouxeram algumas novidades e avanços significativos no sistema de relações trabalhistas no futebol brasileiro e, consequentemente, nas condições sócio profissionais dos futebolistas. No entanto, entendemos que o processo em curso se trata de uma "modernização conservadora", ou seja, um processo incompleto, pois alguns aspectos da nova legislação apontam para uma situação híbrida (inovações em determinados aspectos, ao lado de mecanismos tradicionais). A modernização em curso mantém algumas características do passe, tais como (a) a dependência do jovem atleta em relação ao clube (ou a escolinhas de futebol, empresários, empresas), (b) os procedimentos referentes a empréstimo e a transferência de atletas em favor dos clubes, e (c) o sistema de multas rescisórias (particularmente dos atletas que recebem mais de dez salários mínimos). A modernização conservadora representa um processo de mudança sem participação efetiva do povo e sem democratização do poder ou da propriedade, de forma que as mudanças institucionais encontravam-se enclausuradas em um formalismo burocrático-conservador e as mudanças produtivas não incorporem a progressiva participação do mundo do trabalho nos excedentes econômicos. No caso do futebol, verifica-se a ausência da participação dos atletas na elaboração e/ou alterações da legislação (RODRIGUES, 2007, 2006, 2004).

A percepção dos atletas sobre esta questão é, segundo dados do Gráfico 1, a seguinte: para 69,07\% dos entrevistados a Lei Pelé modernizou alguns elementos do nosso futebol. Essa informação é, por demais, importante para defendermos a tese segundo a qual a Lei Pelé

\footnotetext{
${ }^{6}$ No sentido utilizado por Florestan Fernandes (1976).
} 


\section{NORUS - v1, n.2, jan- jun 2014.}

representa mais uma face da modernização conservadora no Brasil, em que as mudanças são feitas de cima, buscando sempre preservar interesses de grupos dominantes, na perspectiva de análise de Fernandes (1976). No caso específico do futebol o que vimos é uma reestruturação do futebol para acomodar os interesses dos dirigentes e empresários, muitas vezes em detrimento dos interesses dos próprios jogadores. Para 17,53\% dos atletas a Lei Pelé teria modernizado plenamente o nosso futebol e 7,22\% consideram que a Lei nada teria mudado no nosso futebol (Gráfico 1).

Podemos dizer que em A Revolução Burguesa no Brasil, Fernandes (1976) analisa a sociedade brasileira na perspectiva da exclusão e da impossibilidade de eliminação total de alguns traços sociais do nosso passado que se encontram mesclados, imbricados com as novas realidades, e, em alguma medida, bloqueando a realização plena da ordem social competitiva. Trata-se, certamente, de uma revolução burguesa que concilia pelo alto e exclui a classe trabalhadora. Um processo capaz de acomodar o moderno e o tradicional.

Por modernização conservadora, concebe-se o processo que implica no desenvolvimento de normas e instituições modernas, mas, mantendo a estrutura de poder arcaica, ou seja, uma mudança orquestrada pelo Estado, na tentativa de acomodar interesses de determinados setores dominantes. Tratar-se-ia de um ajustamento da sociedade brasileira à modernidade capitalista. As classes responsáveis pela dominação tentaram ajustar a sociedade brasileira ao capitalismo internacional em transformação e, ao mesmo tempo, preservar o caráter geral presente na própria gênese da sociedade brasileira. A solução encontrada foi à modernização conservadora, isto é, um processo de mudança sem povo e sem democratização do poder ou da propriedade, de forma que as mudanças institucionais encontravam-se enclausuradas em um formalismo burocrático-conservador e as mudanças produtivas não incorporavam a progressiva participação do mundo do trabalho nos excedentes econômicos. Nas análises de Fernandes (1976), a modernização não é em si mesma um fator que produziria mudanças da situação ou de superação efetiva das iniquidades socioeconômicas, culturais e políticas. Ou seja, podemos dizer que na concepção do referido autor a modernização teria sido estritamente econômica, resultado da cristalização da dependência, dos meios coercitivos por parte das classes privilegiadas e das desigualdades existentes.

A modernização pela qual passou a sociedade brasileira no século $\mathrm{XX}$, portanto, seria considerada conservadora pelo fato de ter ocorrido uma modernização nos meios de produção, mas não nas relações de produção. 
A Lei Pelé, o fim do passe e a modernização conservadora do futebol-negócio no Brasil: uma análise das percepções dos jogadores

GRÁFICO 1 - Modernização do futebol pela Lei Pelé

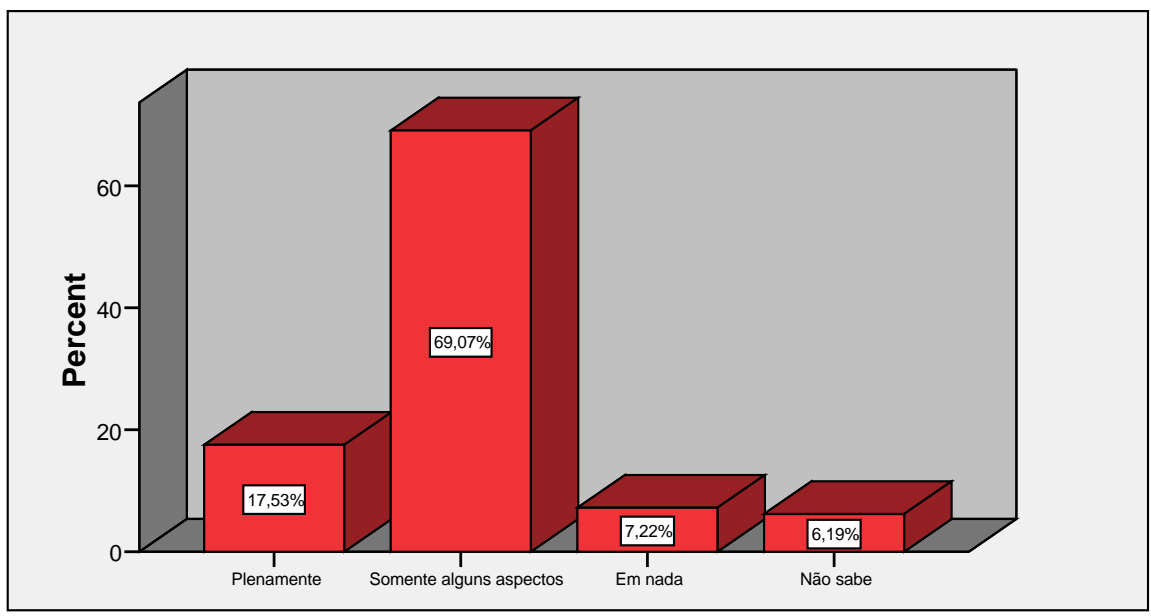

Fonte: Rodrigues (2007, p. 254)

Quanto à relação entre o nível de escolaridade dos jogadores e a percepção dos mesmos sobre a modernização do futebol brasileiro a partir da Lei Pelé, constatamos que a maioria dos atletas com maior nível de escolaridade respondeu que a Lei Pelé modernizou somente alguns aspectos do futebol brasileiro (81,8\%). Os jogadores com maior nível de escolaridade certamente avaliam a lei Pelé com mais propriedade, de forma cautelosa (RODRIGUES, 2007, p. 254).

Em estudos anteriores, Rodrigues (2007, p. 254-255) já constatou que existiria uma leve tendência de que quanto maior o nível de sindicalização maior seria o percentual de jogadores que consideraram que teria havido uma modernização incompleta no futebol brasileiro com a nova legislação que entrou em vigor com a Lei Pelé. Os atletas sindicalizados acreditariam mais na modernização do futebol brasileiro pela Lei Pelé do que os não sindicalizados, mesmo que essa modernização seja restrita a alguns aspectos, ou seja, incompleta. 
NORUS - v1, n.2, jan- jun 2014.

\section{PERCEPÇÃO DOS ATLETAS ENTREVISTADOS SOBRE O FIM DO PASSE COMO UMA TRANSIÇÃO DE UM SISTEMA TRADICIONAL DE TRANSFERÊNCIAS DE JOGADORES PARA UM SISTEMA MODERNO E FLEXÍVEL}

Nesta seção, analisaremos a percepção dos jogadores pesquisados sobre o fim do passe como uma passagem de um sistema tradicional de transferências e de relações de trabalho no futebol brasileiro para um sistema moderno. Pode-se, então, dizer que a nova legislação que estabeleceu o fim do passe inovou no sentido de decretar o direito ao trabalho como algo que deve fazer parte do mercado de trabalho esportivo e um direito inegável ao cidadão.

O Gráfico 2 mostra a visão dos jogadores sobre o fim do passe e a transição do sistema de transferências e de relações entre clubes e jogadores.

GRÁFICO 2 - Fim do passe como transição de um modelo de transferência tradicional para um modelo moderno e flexível

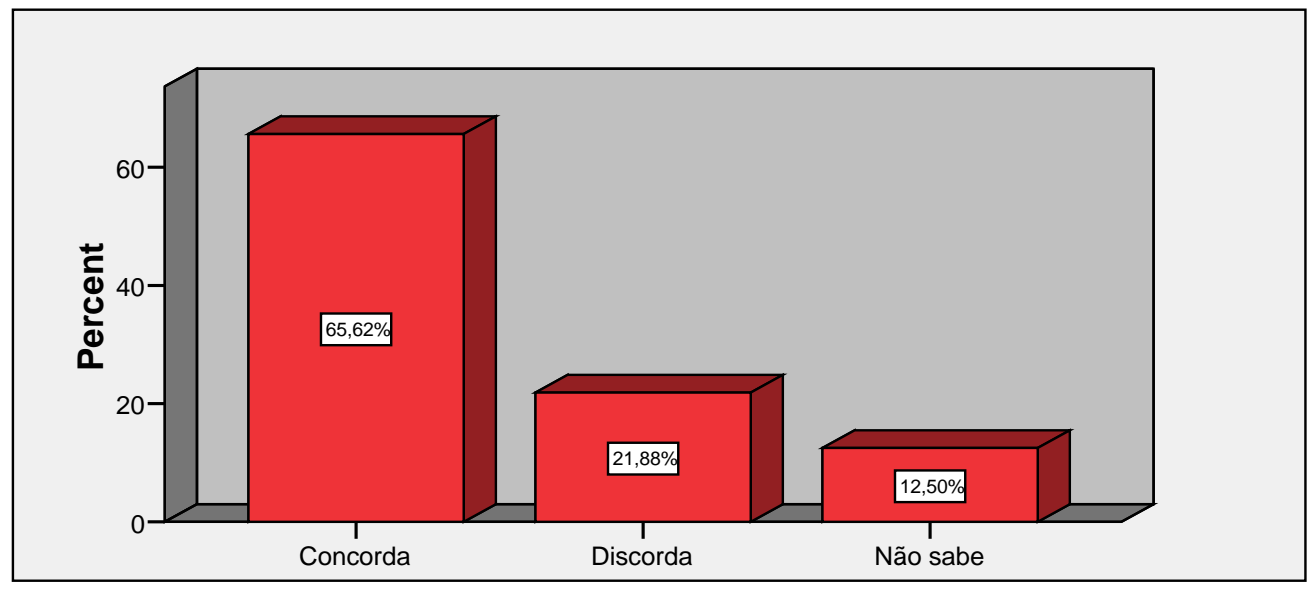

Fonte: Rodrigues (2007, p. 255)

Entendemos que o fim do passe teria representado a passagem ${ }^{7}$ de um modelo de relações de trabalho tradicional (paternalista) para um modelo moderno e flexível, ao estabelecer a liberdade de trabalho para os jogadores e ao flexibilizar os contratos e relações de trabalho. Tendo isso como hipótese, buscamos apreender a visão dos jogadores sobre esta questão. Constatamos que cerca de $65,62 \%$ dos entrevistados concordam que o fim do passe fez a transição de um padrão tradicional de relações de trabalho para um padrão mais moderno. Essa concepção dos atletas corrobora a mesma perspectiva defendida em nossa tese de doutorado (RODRIGUES, 2007), uma das quais advoga que a Lei Pelé (nº 9.615/98) ao decretar o fim do passe teria criado as condições legais para uma modernização do futebol

\footnotetext{
${ }^{7}$ Essa passagem é incompleta, pois a modernização que a Lei Pelé implementou no futebol brasileiro é
} inconclusa, uma modernização conservadora. 


\section{A Lei Pelé, o fim do passe e a modernização conservadora do futebol-negócio no Brasil: uma análise das percepções dos jogadores}

brasileiro: redefinindo as relações entre clubes, entre empresários e entre jogadores de futebol e estabelecendo a liberdade de trabalho aos atletas através da flexibilização do sistema de transferências. Outros elementos concretos, além do entendimento dos jogadores, também indicam essa transição. A liberdade contratual seria um elemento moderno, enquanto o passe, uma dimensão tradicional do padrão de relações entre clubes e jogadores de futebol, o qual está sendo superado pela Lei Pelé.

No entanto, é importante também frisar que $21,88 \%$ dos entrevistados discordaram da pergunta e 12,50\% dos jogadores sequer souberam responder. Esse dado revela que o fim do passe ainda é um tema complexo e que são realmente poucos os atletas que se informam e opinam sobre esta questão com propriedade e conhecimento (Gráfico 2). A maioria dos atletas vive um mundo à parte, deixando seus negócios para seus empresários, o que faz com que não tenha uma opinião mais elaborada sobre questões cruciais do mercado de trabalho no futebol, como é o fim do passe, por exemplo.

Há uma tendência que apontaria uma relação entre o maior nível de instrução e uma maior concordância com os benefícios que o fim do passe realizou no sistema de transferência de atletas tradicional para um sistema moderno (RODRIGUES, 2007, p. 256-257).

\section{CONCEPÇÕES DOS JOGADORES ENTREVISTADOS SOBRE AS PRINCIPAIS INTENÇÕES DA LEI PELÉ}

Abordaremos a partir de agora as concepções dos jogadores entrevistados sobre as principais intenções da Lei Pelé.

Para analisar melhor as transformações provocadas pela Lei Pelé, consideramos necessário conhecer a percepção/opinião dos atletas pesquisados sobre os efeitos da referida lei no futebol brasileiro. O Gráfico 3 apresenta dados acerca da visão dos jogadores sobre as principais intenções da Lei Pelé. Temos, então, 37,11\% dos jogadores entrevistados que afirmaram que as principais intenções da Lei Pelé eram modernizar as relações entre clubes e jogadores e melhorar a situação dos jogadores. Esse grupo de atletas tem uma avaliação que se aproxima das nossas hipóteses, pois acreditamos que a modernização empreendida pela lei acima citada teve o intuito de libertar o atleta do antigo sistema de transferências que se pautava no passe, melhorando a situação dos trabalhadores da bola ao estabelecer a liberdade 
NORUS - v1, n.2, jan- jun 2014.

de trabalho. O objetivo seria de fato trazer melhorias para os jogadores, como afirma Rodrigues (2007, p. 258).

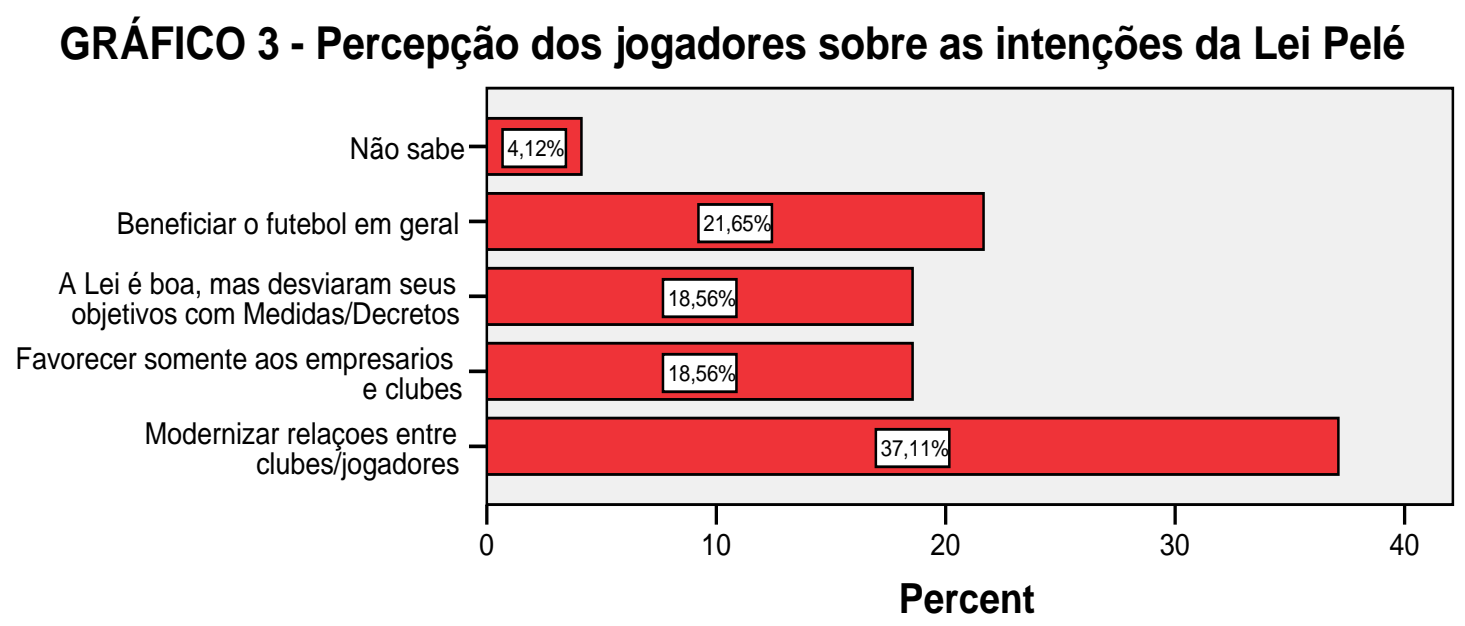

Fonte: Rodrigues (2007, p. 259)

É importante também destacar que $21,65 \%$ dos jogadores responderam que as intenções da Lei Pelé seriam beneficiar o futebol como um todo, criando melhores condições para a ação de todos os segmentos envolvidos neste negócio. Temos aqui mais uma avaliação positiva da nova legislação feita pelos jogadores. Isso é importante para nossa análise, pois, permite-nos confrontar com a avaliação feita por outros atores sociais que participam do futebol, tais como dirigentes, empresários e jornalistas.

Verificamos ainda duas grandes tendências entre os jogadores no que se refere às intenções da Lei Pelé - uma formada por 18,56\% entrevistados defende que a Lei Pelé é boa, mas as alterações sobre ela (Medidas e Decretos) teriam desviado seu objetivo principal, o que teria favorecido os interesses dos dirigentes e dos empresários (Gráfico 3).

A outra tendência agrupa também $18,56 \%$ dos jogadores entrevistados e aponta que a Lei Pelé é percebida como favorável aos clubes e aos empresários, sem se preocupar com os jogadores. Logo, segundo essa avaliação, a lei não teria sido boa para os jogadores (Gráfico $3)$.

Já vimos acima a posição dos atletas sobre as principais intenções da Lei Pelé. A intenção principal da Lei Pelé era melhorar a situação dos jogadores e estabelecer um sistema moderno de relações trabalhistas. Mesmo com as medidas posteriores que alteraram o ideal geral da nova legislação, não se pode negar que houve um avanço no processo de modernização das relações de trabalho no futebol. A extinção do passe, então, significou, acima de tudo, a erradicação de um mecanismo tradicional ("passe") que possibilitava que um 


\section{A Lei Pelé, o fim do passe e a modernização conservadora do futebol-negócio no Brasil: uma análise das percepções dos jogadores}

profissional ficasse sem trabalhar, sem receber salários e sem poder buscar um novo empregador por vontade de seu "dono", representado na figura do cartola. Com o fim do passe teria se estabelecido um sistema de relações entre clubes e jogadores mais equilibrado. É por essa razão que a extinção do passe criou um novo cenário no mercado futebolístico brasileiro. Outra inovação da Lei Pelé foi o sistema de indenizações e multas, mostrando que a relação entre clube e jogador deveria ser entendida e tratada como uma relação moderna de trabalho.

\section{AVALIAÇÃO DOS JOGADORES SOBRE OS IMPACTOS/EFEITOS MAIS IMPORTANTES DO FIM DO PASSE NO FUTEBOL BRASILEIRO}

Um dos objetivos deste artigo é exatamente identificar e analisar os principais impactos (efeitos/consequências/implicações) do fim do passe no futebol brasileiro. Estamos investigando não somente os aspectos mais concretos, tais como as mudanças nos contratos de trabalho, o aumento das transferências internacionais, a maior mobilidade interna de jogadores, as novas orientações na política de formação de atletas, como também, buscando apreender a concepção dos jogadores sobre estas mudanças provocadas pelo fim do passe.

A Lei Pelé parece realmente ter a intenção de modernizar as relações de trabalho e os contratos entre clubes e jogadores, e claro, o que viria a melhorar a situação dos profissionais da bola (os jogadores).

O Gráfico 4 nos apresenta algumas estimativas a respeito da avaliação dos jogadores entrevistados sobre os efeitos mais importantes do fim do passe no futebol brasileiro. 


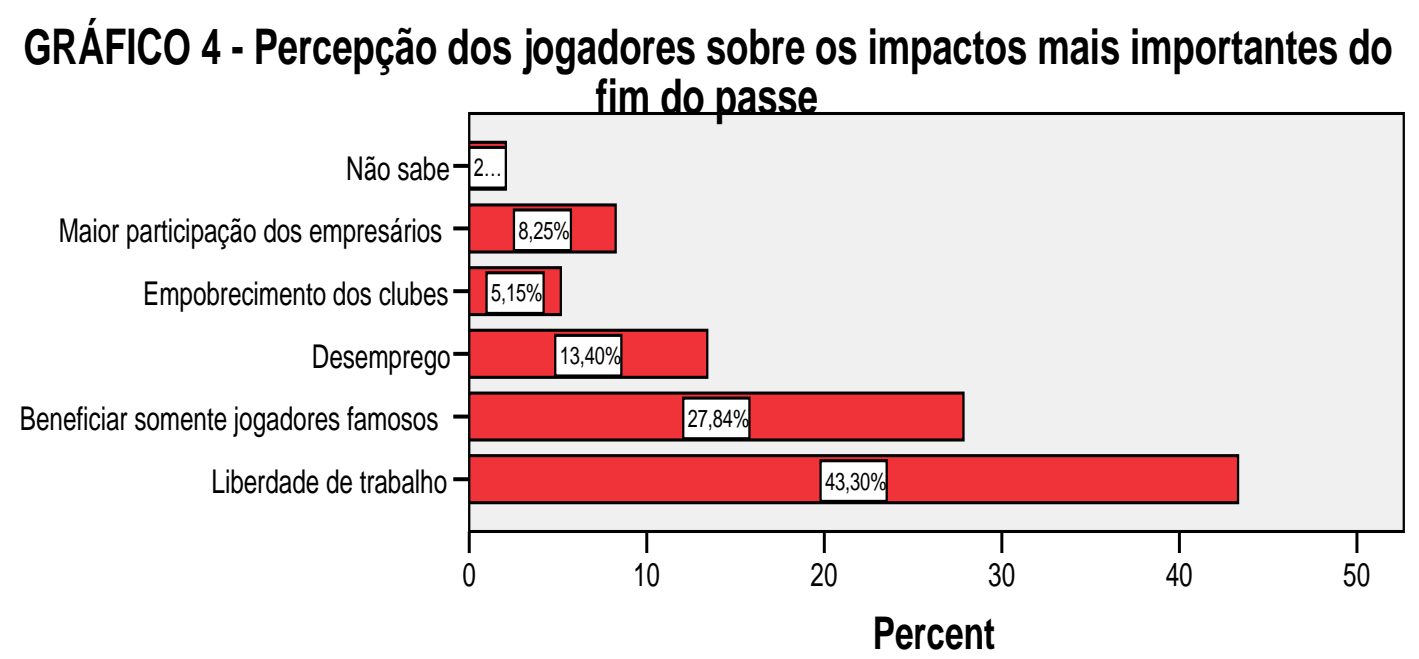

Fonte: Rodrigues (2007, p. 262)

Conforme Rodrigues (2007 , p. 262), a opinião dos jogadores é condizente com a proposta principal da Lei Pelé ( $n^{\circ}$ 9.615/98) que é estabelecer liberdade de trabalho para os jogadores ao extinguir o passe, aquele sistema tradicional de relações entre clubes e atletas. Cerca de $43,3 \%$ dos jogadores entrevistados elegeram a liberdade de trabalho como o efeito/impacto mais importante do fim do passe. Esse dado é muito importante para a nossa análise, servindo de importante ferramenta para enfrentar o discurso de jornalistas e dirigentes esportivos fundamentado em argumentos totalmente desfavoráveis à Lei Pelé.

Vimos ainda que para $27,84 \%$ dos entrevistados o fim do passe é bom apenas para uma parcela de jogadores, especialmente aqueles que já têm seu nome feito no mercado futebolístico, pois a Lei chegou para beneficiar somente os jogadores já famosos. É comum ouvirmos esses argumentos nas entrevistas de alguns atletas, bem como e comentários de jornalistas esportivos. Entendemos que essa posição tem uma certa lógica (RODRIGUES, 2007, p. 262)

Percebe-se também que para 13,40\% dos atletas o fim do passe teve como principal efeito o desemprego. Essa é uma avaliação mais negativa. É verdade que nos últimos anos temos mais jogadores desempregados. O desemprego representa um dos mais graves problemas da economia mundial, sendo também muito mais acentuado nas últimas décadas em decorrência do processo de globalização da economia e das mudanças no mundo do trabalho (LARANJEIRA, 1997; GIDDENS, 2004).

Há ainda um pequeno grupo de atletas, algo em torno de 8,2\% dos entrevistados que responderam que o fim do passe teve como principal efeito a maior participação dos empresários no futebol. No entanto, o fim do passe não tinha intenção de favorecer aos 


\section{A Lei Pelé, o fim do passe e a modernização conservadora do futebol-negócio no Brasil: uma análise das percepções dos jogadores}

empresários, mas de modificar o sistema de relações contratuais no nosso futebol, até porque a nova legislação praticamente não faz alusão à figura do empresário (AFIF, 2006).

\section{OPINIÃO DOS JOGADORES ENTREVISTADOS SOBRE OS SETORES (E ATORES) MAIS FAVORECIDOS PELO FIM DO PASSE}

Quando discutimos a questão de quem foi mais beneficiado com a Lei Pelé e com o fim do passe, estamos muitas vezes tratando de um debate acentuadamente subjetivo. Se partirmos do ponto de vista dos jogadores, é evidente que teremos um olhar diferente daquele dos empresários. Pode-se dizer que dependendo dos interesses e compromissos de quem observa a atual transformação pela qual passa o futebol brasileiro, a modernização pode ser avaliada como 'benéfica', "boa” ou como 'problemática', “confusa”. Na verdade, depende muito da direção do processo de modernização. Este pode favorecer mais aos atletas ou aos clubes e empresários, conforme a orientação adotada pelos gestores do processo modernizante.

\footnotetext{
Dependendo das possibilidades de competir nos novos mercados, as mudanças podem ser vistas como 'promissoras' ou 'destrutivas'. [...], como as perspectivas do futebol-empresa acabam dependendo do comportamento de mercados mais amplos, nos quais a comercialização do espetáculo futebolístico se insere, no momento há mais dúvidas do que certezas a respeito dos resultados dessa transição [...] (PRONI, 2001, p. 04).
}

A Lei Pelé veio modernizar o futebol brasileiro, modificando os contratos e as relações de trabalho entre clubes e jogadores. Sabemos que os seus efeitos são recentes e nem sempre agradam a todos os setores do futebol. O mercado futebolístico funciona mesmo como um campo, formado por atores sociais com interesses diferenciados. Por isso o fim do passe pode ter agradado mais aos jogadores do que aos dirigentes, ou também pode ter favorecido mais aos empresários do que aos jogadores e dirigentes. Para saber exatamente isso seria necessária uma investigação cuidadosa, conforme defende Rodrigues (2007, p. 265).

$\mathrm{Na}$ tentativa de apreender a avaliação dos jogadores entrevistados sobre os segmentos (atores) ligados ao futebol que foram mais favorecidos com o fim do passe, obtivemos resultados interessantes, como pode ser visualizado no Gráfico 5. Cerca de 32,99\% dos atletas responderam que os jogadores foram os mais favorecidos com o fim do passe. Nossa hipótese central de trabalho segue nessa direção, ou seja, a de que o fim do passe teria de fato 
melhorado as relações trabalhistas no futebol brasileiro, tendo como preocupação central o bem do atleta, do trabalhador.

Uma parcela significativa de atletas afirmou que o fim do passe favoreceu mais aos empresários (26,80\%). Estes teriam sido os mais beneficiados pela nova legislação. Parte da imprensa também pensa assim, e defendem que a Lei Pelé penalizou os clubes e somente ajudou aos empresários. É importante destacar que algo em torno de 16,49\% dos entrevistados acredita que o fim do passe favoreceu ao futebol como um todo, sendo todos os segmentos beneficiados. Verifica-se também que $11,34 \%$ dos entrevistados responderam que o fim do passe favoreceu mais aos clubes e somente $4,12 \%$ dos atletas afirmaram que o fim do passe gerou uma crise geral no futebol, prejudicando a todos. Essa é uma posição defendida também por alguns jornalistas esportivos, como Wianey Carlet, do jornal Zero Hora de Porto Alegre RS. Nosso entendimento é de que esta é uma concepção equivocada, visto que o futebol brasileiro já estava em crise antes do fim do passe entrar em vigor. Portanto, os argumentos dessa concepção são frágeis. Alega-se que a Lei Pelé foi elaborada com o intuito de quebrar os clubes brasileiros ao lhe tirar o direito de vender os atletas. Os clubes brasileiros enfrentam crises financeiras há algum tempo, já que são muito mal administrados e o mercado consumidor de futebol, formado pela torcida, é pobre se comparado ao mercado europeu.

\section{GRÁFICO 5 - Percepção dos atletas sobre setores mais favorecidos pelo fim do passe}
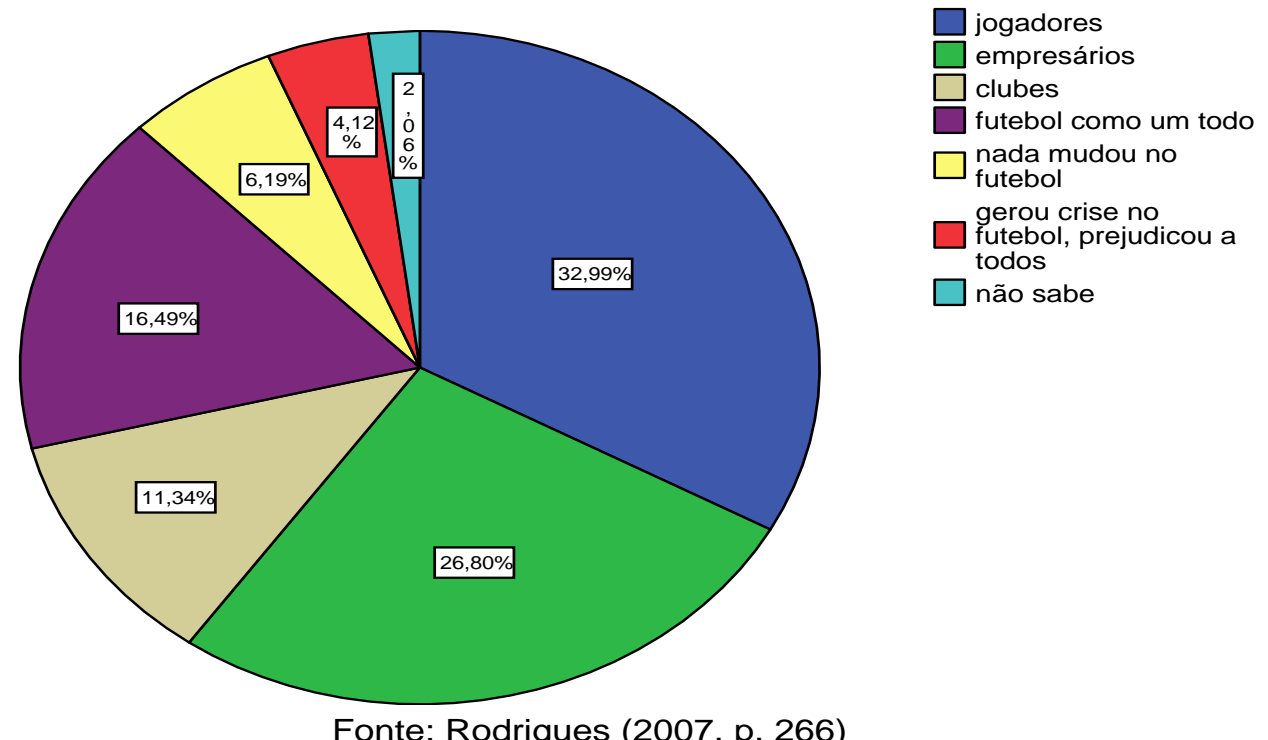

Fonte: Rodrigues (2007, p. 266)

Neste artigo, defendemos o argumento de que os jogadores e os clubes de futebol foram os setores mais beneficiados pelo fim do passe. Os jogadores ganharam liberdade de trabalho, melhores condições para negociar os contratos, e os clubes podem ganhar se fizerem 


\section{A Lei Pelé, o fim do passe e a modernização conservadora do futebol-negócio no Brasil: uma análise das percepções dos jogadores}

um bom trabalho na formação de atletas e se souberem criar mecanismos (contemplados pela lei) para reter os jovens jogadores. $\mathrm{Na}$ verdade, é importante ressaltar que mesmo alguns dirigentes defendendo que os empresários teriam sido os mais beneficiados pela Lei Pelé, é necessário ressaltar que a referida lei não trata de empresários. Buscava, em sua essência, criar mecanismos gerais para o desenvolvimento do futebol no país. Todos os setores envolvidos no mundo do futebol que desejam uma realidade nova e organizada ganharam com o fim do passe. As avaliações sobre os efeitos do fim do passe são os mais diversos, dependem diretamente dos interesses dos atores que fazem parte desse meio. É nesse sentido que o conceito de campo, conforme Bourdieu (2000) é muito útil nessa análise. Por campo entendemos um espaço de diferenciação social, que funciona de acordo com regras e normas próprias, dotado de autonomia relativa frente à política, à economia e à religião. No campo existem atores sociais estratégicos preocupados que buscam maximizar seus interesses e influenciar nas definições e divisões sociais, existindo disputas por capitais materiais e simbólicos (BOURDIEU, 2000).

\section{A PERCEPÇÃO DOS ATLETAS ENTREVISTADOS SOBRE PROFISSIONALIZAÇÃO PRECOCE DE JOGADORES E REJUVENESCIMENTO DA FORÇA DE TRABALHO NO FUTEBOL BRASILEIRO}

7.1. Visão dos atletas sobre causas da profissionalização precoce de jogadores de futebol no Brasil

A profissionalização dos jogadores de futebol tem sido antecipada, ou seja, ocorre cada vez mais cedo. Os atletas estão assinando contratos de trabalho com os clubes ainda muito jovens, antecipando o ingresso no grupo dos profissionais. A legislação atual (Lei Pelé) permite contratos já a partir dos 16 anos. Não há dúvidas de que a flexibilização dos contratos e das relações de trabalho no futebol brasileiro desencadeada pela Lei Pelé fez com que as possibilidades de profissionalização dos atletas aumentassem. A flexibilidade em curso na nossa economia implica em um modelo de desregulamentação e mudanças no papel e na extensão das leis (SUPERVIELLE \& QUIÑONES, 2000, p. 24).

Uma das hipóteses do nosso trabalho é de que com o fim do passe (resultado da Lei Pelé) os jogadores passaram a se tornar profissionais com menor idade, mais cedo. Esta 


\section{NORUS - v1, n.2, jan- jun 2014.}

hipótese tem sustentação na literatura jurídica sobre o futebol e pode ser comprovada a partir da concepção dos jogadores. Perguntamos aos atletas quais seriam os motivos pelos quais a profissionalização é cada vez mais precoce. Os resultados estão ilustrados no Gráfico 6. Este mostra que 31,96\% dos atletas acreditam que o fim do passe veio obrigar os clubes a assinar contratos com os atletas jovens, em formação, para garantir direitos sobre os atletas, sob pena de perderem para outros clubes. A legislação corrente admite que o clube formador tenha preferência no primeiro contrato profissional, sendo uma forma de ressarcir o clube pelos investimentos na formação do atleta. A visão dos atletas se insere na perspectiva legal.

Há ainda um conjunto de 26,80\% (26 atletas) de entrevistados que afirmaram que a profissionalização dos jogadores é mais cedo hoje no Brasil porque o fim do passe flexibilizou as relações entre clubes e jogadores, facilitando as transferências. Isso é verdade e se adéqua aos atuais parâmetros legais do nosso futebol (RODRIGUES, 2007).

Para 26,80\% dos entrevistados, a profissionalização dos jogadores é cada vez mais precoce, isso ocorreria não exatamente devido à legislação e sim devido à crise financeira pela qual passam os clubes brasileiros. Estes seriam obrigados a aproveitar os atletas formados nas categorias de base, os chamados pratas-da-casa, pois não teriam recursos para contratar jogadores consagrados no mercado. Trata-se também de uma hipótese interessante, podendo ser um dos motivos que impulsiona esse movimento de profissionalização precoce no futebol brasileiro, levando ao rejuvenescimento da força de trabalho no futebol pentacampeão do mundo (RODRIGUES, 2007, p. 269).

Para 13,40\% dos jogadores entrevistados, o fim do passe não influenciou a profissionalização precoce de jogadores no futebol brasileiro. 


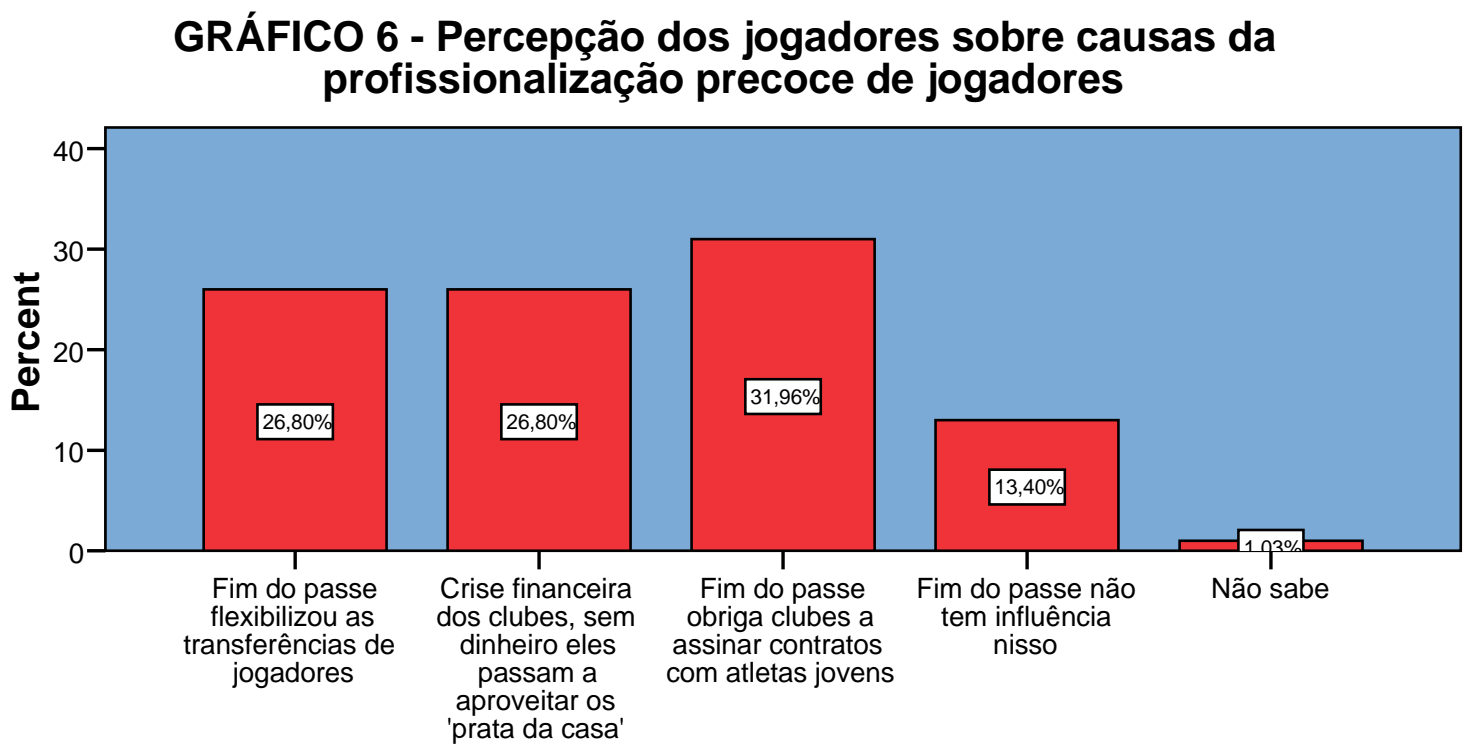

Fonte: Rodrigues (2007, p. 269)

Os jogadores estão se profissionalizando mais cedo no futebol brasileiro por uma série de fatores, entre eles apontamos a globalização do futebol, as mudanças na legislação (Lei Pelé) e a crise financeira dos clubes brasileiros. Os atletas estão se profissionalizando mais cedo devido à expansão do mercado internacional de jogadores, ou seja, a procura por jogadores brasileiros já formados e consagrados, levando os clubes brasileiros a recorrem aos atletas das categorias de base, formadas em casa, nas escolinhas dos clubes (RODRIGUES, 2007, 2006, 2004).

Além dos fatores acima mencionados, é importante frisar os próprios critérios de profissionalização adotados no Brasil, também a falta de organização no futebol brasileiro e, ainda, a enorme busca por esta profissão aqui no nosso país.

Podemos ainda acrescentar um outro elemento que pode justificar a profissionalização mais cedo de jogadores, ou seja, a necessidade de atletas jovens: trata-se do fato de que o futebol atualmente é jogado muito em cima do condicionamento físico dos atletas (RODRIGUES, 2007, p. 270).

Podemos ainda afirmar que a profissionalização precoce de jogadores é uma consequência direta da Lei Pelé, pois os clubes temem que o atleta em formação ou recémformado assine contrato com outros clubes e acabe por antecipar os contratos. Na verdade, para não perder o que investiram, os clubes começam a aproveitar os jogadores mais cedo, quando ainda nem completaram seu ciclo de fundamentos de futebol. O primeiro contrato também é, muitas vezes, mais longo para evitar, ou tentar, a rapinagem do mercado exterior. 


\section{NORUS - v1, n.2, jan- jun 2014.}

Os clubes brasileiros estão aproveitando mais os jogadores formados em casa por necessidade, visto que muitos deles não têm condições de contratar atletas no mercado e acabam descobrindo a verdadeira finalidade das categorias de base que é formar atletas para o futebol. De certa forma, os clubes estão percebendo que a formação tem essa finalidade e não a de ressarcimento.

7.2. Avaliação dos jogadores sobre a influência do fim do passe no rejuvenescimento da força de trabalho no futebol brasileiro

A extinção do passe ocorreu oficialmente em 25 de março de 2001, conforme art. 96 da Lei ${ }^{\circ}$ 9.615/98. O sistema de relações entre clubes e jogadores com base no passe vigorou de 1976 a 2001, foi criado pelo art. 11 da Lei ${ }^{\circ}$ 6.354/76. O passe é/era o vínculo desportivo do atleta com a entidade (clube) contratante, que tem natureza acessória ao "respectivo vínculo empregatício, dissolvendo-se, para todos os efeitos legais com o término da vigência do contrato de trabalho" (NAPIER, 2003, p. 260).

O rejuvenescimento da força de trabalho no futebol brasileiro com o fim do passe significa que os atletas se profissionalizam cada vez mais jovens, em consequência da escassez de recursos para contratações e negociações de jogadores e da flexibilização nas relações clubes/jogadores promovida pela nova legislação. A média de idade dos clubes brasileiros é cada vez mais baixa (RODRIGUES, 2007, p. 273).

O fim do passe tem influenciado bastante isso que estamos denominando de rejuvenescimento da força de trabalho no futebol brasileiro. Como pode ser observado no Gráfico 7, a nossa pesquisa constatou que 53,68\% dos jogadores consideram que o fim do passe influenciou no rejuvenescimento dos jogadores no Brasil, fazendo com que os clubes apresentem jovens atletas, a média de idade baixa, ficando entre 20 e 25 anos. É expressivo também o percentual de jogadores que não souberam responder (27,37\%). Entende-se isso, pois realmente não é uma questão fácil, as evidências não são explícitas. Entretanto, cerca de $18,96 \%$ dos jogadores responderam que o fim do passe não tem influência no rejuvenescimento. 


\section{GRÁFICO 7 - Percepção sobre fim do passe e rejuvenescimento da força de trabalho no futebol brasileiro}

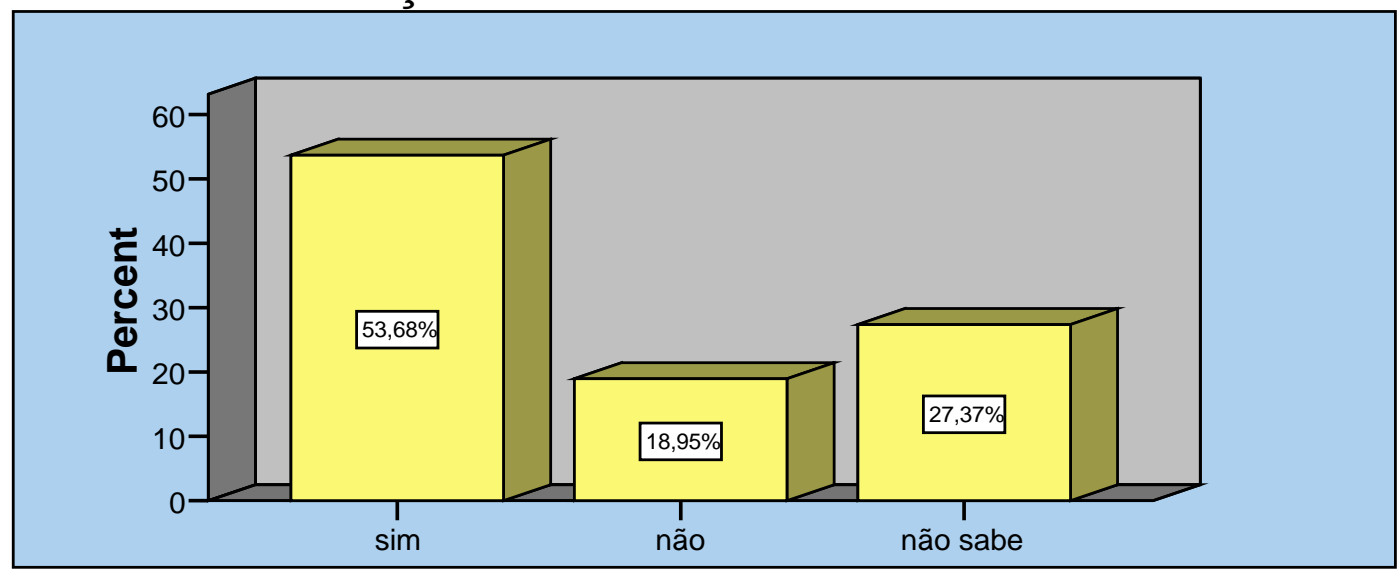

Fonte: Rodrigues (2007, p. 274)

Não temos dúvidas sobre isso pelo fato de que a legislação que estabelece o fim do passe também permite que os clubes assinem contratos com jogadores cada vez mais jovens. O fim do passe também deixa jogadores jovens, teoricamente, livres para assinar contratos com outros clubes e isso influencia no rejuvenescimento do futebol brasileiro.

\section{CONSIDERAÇÕES FINAIS}

A questão central que fundamenta o debate desenvolvido neste estudo refere-se à análise dos impactos do fim do passe no futebol brasileiro e à apreensão das características da modernização conservadora que se manifestam no conjunto de transformações pelas quais passa o mercado futebolístico nacional no contexto da sociedade brasileira.

Analisamos as concepções dos jogadores brasileiros sobre os impactos da Lei Pelé e do fim do passe no mercado futebolístico nacional. Enfatizamos as percepções dos atletas acerca dos efeitos provocados pela nova legislação sobre a modernização do futebol, o sistema de relações de trabalho e de contratos entre clubes e jogadores, as principais intenções da Lei Pelé, os setores mais favorecidos com o fim do passe, as influências do fim do passe no sistema de transferências de atletas e na mudança na idade da profissionalização dos jogadores.

Um dos argumentos centrais deste artigo é de que a Lei Pelé e o fim do passe redefinem as relações entre clubes/empresários/jogadores de futebol pela flexibilização do 


\section{NORUS - v1, n.2, jan- jun 2014.}

sistema de transferência de jogadores, e representam a passagem de um sistema tradicional, rígido, servil e paternalista, para um sistema moderno, flexível e contratual. Trata-se de uma nova regulamentação do sistema de transferências de jogadores e de relações de trabalho no futebol, mas não significa a plena liberdade de trabalho do jogador de futebol devido aos mecanismos que continuam vinculando o jogador ao clube, como a cláusula penal, o sistema de multas rescisórias e as indenizações de formação e de promoção de jogadores. Por isso, o fim do passe (produto da Lei Pelé) tende a criar um sistema híbrido de relações entre clubes, jogadores e empresários. No entanto, o fim do passe não foi suficiente para abolir os mecanismos de negociação e venda de jogadores e as correspondentes taxas de intermediação, o que implica uma dimensão da modernização conservadora. Na verdade, foram criados mecanismos (indenizações em caso de rompimento do contrato de trabalho, indenizações por formação e promoção dos jogadores e cláusula penal) que "prendem" o atleta aos clubes e/ou aos empresários.

A seguir, são resumidas as principais constatações deste trabalho, construídas a partir das evidências apresentadas ao longo do texto.

- Em relação à modernização do futebol brasileiro pela Lei Pelé, a percepção predominante dos atletas é de que a referida lei modernizou somente alguns elementos do nosso futebol $(69 \%)$. Trata-se de um dado muito relevante na presente análise, pois defendemos a tese de que a Lei Pelé representa mais uma face da modernização conservadora no Brasil, em que a maioria das mudanças são impostas de cima, na tentativa de preservar interesses de grupos dominantes, tal com entende Florestan Fernandes (1976) na sua análise sobre a Revolução Burguesa no Brasil. No caso do futebol, ocorreu uma reestruturação desta modalidade esportiva (sobretudo no âmbito profissional) para acomodar os interesses dos dirigentes e empresários, muitas vezes em detrimento dos interesses dos jogadores. Para 17\% dos jogadores, a Lei Pelé modernizou plenamente o nosso futebol (Gráfico 1).

- Entende-se que o fim do passe representou a passagem de um modelo tradicional de relações de trabalho para um modelo moderno e flexível, pois decretou a liberdade de trabalho para os jogadores e flexibilizou os contratos e relações de trabalhista. Mais de $64 \%$ dos atletas pesquisados acreditam que o fim do passe fez a transição de um padrão tradicional de relações de trabalho (Gráfico 2).

- Os principais objetivos da Lei Pelé eram exatamente inserir o futebol brasileiro no padrão empresarial e modernizar a sua estrutura, introduzindo novos mecanismos legais (consolidação de leis, regras e instituições regulamentadora do esporte, processo esse que 


\section{A Lei Pelé, o fim do passe e a modernização conservadora do futebol-negócio no Brasil: uma análise das percepções dos jogadores}

corresponde a uma das características essenciais do processo civilizador na concepção de Norbert Elias (1993, 1992a, 1992b) e modernização no sentido de processos de mudança intencional, que podem ser conectados à radicalização da modernidade, no sentido utilizado por Anthony Giddens (1997, 1991, 1989). Um dos pontos importantes dessa modernização do futebol, sobretudo da nova legislação e do sistema de transferência de jogadores, é o estabelecimento do fim do passe. Acreditamos que a mais importante inovação da Lei Pelé foi de fato a extinção do passe.

- A maioria dos jogadores entrevistados $(37,1 \%)$ considera que as principais intenções da Lei Pelé seriam as de modernizar as relações entre clubes e jogadores para melhorar a situação dos profissionais do futebol. Cerca de 21,6\% dos jogadores responderam que as intenções da Lei Pelé eram beneficiar o futebol como um todo (Gráfico 3). Outra opinião é que a Lei Pelé é boa, mas as alterações sobre ela (Medidas e Decretos) desviaram do seu objetivo principal, favorecendo aos interesses dos dirigentes e dos empresários.

- Em relação aos impactos mais importantes do fim do passe, os atletas destacaram a liberdade de trabalho, benefício somente de jogadores famosos, desemprego, maior participação dos empresários no futebol e empobrecimento dos clubes, nessa ordem de importância.

- Os setores mais beneficiados pelo fim do passe, segundo a avaliação dos entrevistados, foram os jogadores, os empresários, o futebol como um todo e os clubes de futebol. Neste artigo, argumentamos que os jogadores e os clubes de futebol foram os mais beneficiados pelo fim do passe. Por um lado, os jogadores ganharam liberdade de trabalho e melhores condições para negociar os contratos e transferências. Por outro lado, os clubes podem ganhar se fizerem um bom trabalho na formação de atletas e souberem criar mecanismos (contemplados pela lei) para reter os jovens jogadores. É importante destacar que, mesmo alguns dirigentes defendendo que os empresários foram os mais beneficiados pela Lei Pelé, é necessário ressaltar que a referida lei não trata de empresários, pois ela busca, em sua essência, criar mecanismos gerais para o desenvolvimento do futebol no país. As ponderações sobre os impactos/efeitos do fim do passe são as mais diversas, e dependem

diretamente dos interesses dos atores que fazem parte desse meio. É por isso que o mercado futebolístico se assemelha a um campo societário, no sentido utilizado por Bourdieu (2000), que entende o campo como um espaço de diferenciação social, no qual os diferentes agentes e atores disputam poderes materiais e simbólicos. Um campo social específico, como nesse caso, o futebol, funciona de acordo com regras e normas próprias, 


\section{NORUS - v1, n.2, jan- jun 2014.}

dotado de autonomia relativa frente à política, à economia e à religião (BOURDIEU, 2000).

- Quanto à profissionalização dos jogadores de futebol, esta tem sido antecipada, ou seja, ocorre cada vez mais cedo. Verificamos que os atletas estão assinando contratos de trabalho com os clubes ainda muito jovens, antecipando seu ingresso no futebol profissional. A legislação atual (Lei Pelé) permite contratos já a partir dos 16 anos de idade. Constatamos que $32 \%$ dos jogadores consideram que a razão da profissionalização precoce é o fim do passe, que obriga os clubes a assinarem contratos com os atletas muito jovens, ainda em formação, para garantir direitos sobre os mesmos, sob pena de os perderem para outros clubes. Para 26,8\% dos atletas, a profissionalização é mais cedo hoje no Brasil porque o fim do passe flexibilizou as relações entre clubes e jogadores, facilitando as transferências. É importante também destacar que 26,8\% dos jogadores pesquisados responderam que a profissionalização dos jogadores é cada vez mais precoce não exatamente devido à legislação, mas devido à crise financeira pela qual passam os clubes brasileiros (Gráfico 6). A alternativa dos clubes é aproveitar os atletas formados nas categorias de base, os chamados pratas-da-casa.

- O fim do passe tem influenciado no rejuvenescimento da força de trabalho no futebol brasileiro. A nova legislação permite que os clubes assinem contratos com jogadores cada vez mais jovens. O fim do passe deixa jogadores jovens teoricamente livres para assinar contratos com outros clubes e isso influencia no rejuvenescimento do futebol brasileiro, visto que o elemento que mantém o atleta vinculado ao clube é o contrato de trabalho, e não mais o passe.

\section{REFERÊNCIAS BIBLIOGRÁFICAS}

AFIF, Antônio. Exportação de jogadores brasileiros (2005/2006). www.cidadedofutebol.com.br (acesso 30/08/2006).

AIDAR, Antônio Carlos Kfouri; LEONCINI, Márvio Pereira \& OLIVERIA, João José de. (Orgs.). A Nova Gestão do Futebol. Rio de Janeiro: Editora da FGV, 2000.

ALTHOFF, Geraldo. Senado Federal. Relatório final da CPI do futebol. Brasília. Dezembro de 2001.

AUDINHO, Sérgio e KLEIN, Marco. O Almanaque do Futebol Brasileiro. São Paulo: Escala, 1996. 


\section{A Lei Pelé, o fim do passe e a modernização conservadora do futebol-negócio no Brasil: uma análise das percepções dos jogadores}

BARROS, Alice M. de. As Relações de Trabalho no Espetáculo. São Paulo: LTr, 2003.

BOUDENS, E. Relações de trabalho no futebol brasileiro II: valor, critérios e condições para o pagamento do passe segundo a resolução/indesp $n^{\circ} 1 / 96$. Estudo, Consultoria Legislativa. Brasília: Câmara dos Deputados, fevereiro de 2002.

- Relações de trabalho no futebol brasileiro III: considerações acerca do prometo de Lei $\mathrm{n}^{\circ}$ 2.437, de 1996. Estudo, Consultoria Legislativa. Brasília: Câmara dos Deputados, fevereiro de 2002.

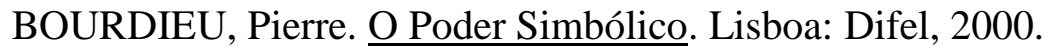

Jeux olympiques: programme pour une analyse. Actes de la Recherche en Sciences Sociales, $n^{\circ}$ 103: 102-3, 1994.

BRAGA, E. A Lei do passe livre. Revista Consultor Jurídico. Ano II - n 15, Julho/2001.

BRASIL Lei 6816/80. Diário Oficial da União. 19/08/80.

CÂNDIA, Ralph. Comentários aos Contratos Trabalhistas Especiais: doutrina, jurisprudência, legislação. São Paulo: LTr, 1995.

CARRAVETTA, Élio Salvador. Modernização da Gestão no Futebol Brasileiro: perspectivas para a qualificação do rendimento competitivo. Porto Alegre: Editora AGE, 2006.

D'OTTAVIANO, R. de O. Fim do passe de jogador: clube deve prestar atenção em outras fontes de receita. Revista Consultor Jurídico, 23 de abril de 2001.

ELIAS, Norbert \& DUNNING, Eric. A Busca de Excitação. Lisboa: Difel, 1992a.

ELIAS, Norbert. Deporte y Ocio en el Proceso de la Civilización. Madrid: Fondo de Cultura Económica, 1992b.

ELIAS, Norbert. O Processo Civilizador: formação do Estado e Civilização. Rio de Janeiro: Zahar, 1992c, volume 2.

FGF. Federação Gaúcha de Futebol. Revista Oficial da Federação Gaúcha de Futebol. Porto Alegre: Adventus, 2000.

FERNANDES, Florestan. A Revolução Burguesa no Brasil: ensaio de interpretação sociológica. Rio de Janeiro: Zahar, 1976.

FLICK, Uwe. Qualidade na pesquisa qualitativa. Porto Alegre: Artmed, 2009.

GIDDENS, Anthony. Sociologia. 4. ed. Lisboa: Fundação Calouste Gulbenkian, 2004.

GIDDENS, Anthony. As Conseqüências da Modernidade. São Paulo: UNESP, 1991.

GIDDENS, Anthony.Modernização Reflexiva: política, tradição e estética na ordem social moderna. São Paulo: UNESP, 1997.

GIDDENS, Anthony. A Constituição da Sociedade. São Paulo: Martins Fontes, 1989. 
GIL, Antonio Carlos. Métodos e técnicas de pesquisa social. São Paulo, Editora Atlas, 1987. Capítulo II. O questionário. Conceituação. Vantagens e limitações do questionário. A construção do questionário. p. 124-132.

GIULIANOTTI, Richard. Sociologia do Futebol: Dimensões Históricas e Socioculturais do Esporte das Multidões. São Paulo: Nova Alexandria, 2002.

GURGEL, A. Futebol S/A A Economia em Campo. São Paulo: Saraiva, 2006.

LARANJEIRA, S. M. G. O trabalho em questão: transformações produtivas e a centralidade do trabalho no século XXI. Revista de Ciências Humanas, v.15, $\mathrm{n}^{\circ}$ 22, Florianópolis-SC: Ed. UFSC, 1997.

MACHADO, J. E. O novo contrato desportivo e a extinção do passe. Justiça do Trabalho. Porto Alegre. V.17, $\mathrm{n}^{\mathrm{o}}$ 203, p 7-13, nov. 2000.

MACIEL, M. R. O contrato de trabalho do jogador de futebol: leis versus realidade. Faculdade de Direito. Centro Universitário Ritter dos Reis. Canoas, 2003. (Trabalho de conclusão de curso).

MARTINS, C. E. Da globalização da economia à falência da democracia. Economia e Sociedade, $N^{\circ}$ 6, IE/Unicamp, 1996.

MELLO FILHO, Á. Nova legislação do desporto (Comentários e atualização)-Leis no s. 9. 615/98 e 9.981/00 e MP 2.141/01). Fortaleza: ABC, 2001.

MELLO FILHO, Á. Novo ordenamento jurídico-desportivo. Fortaleza: ABC, 2000.

MINAYO, M. C. S. (Org.). Pesquisa Social: teoria, método e criatividade. Petropolis: Vozes, 2001.

NAPIER, R. D. Manual do Direito Desportivo e Aspectos Previdenciários. São Paulo: IOB, 2003.

OLIVIER, Diogo. O drama social do mundo da bola. Zero Hora, Porto Alegre, 21 out. 2001, Esportes. p. 56.

PAIVA, R. T. Aspectos do contrato de trabalho de atleta profissional de futebol. Revista da

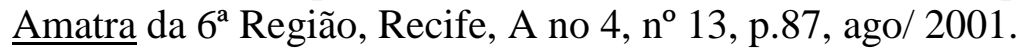

PERRY, V. Código Brasileiro Disciplinar de Futebol. 2. ed. Rio de Janeiro: Editora Lúmen Júris, 2000.

PRONI, Marcelo. A Modernização do futebol brasileiro, en SEMINARIO VIRTUAL SOCIEDAD Y ORGANIZACIONES DEPORTIVAS CEO José B. Zubiaur - Villa Mercedes (San Luis) Argentina, 2001.

PRONI, Marcelo. A Metamorfose do Futebol. Campinas: UNICAMP, 2000.

Relações de Trabalho no Futebol Brasileiro III: considerações acerca do projeto de Lei $\mathrm{n}^{\mathbf{o}}$ 2.437/1996. Consultoria Legislativa. Estudo, Câmara dos Deputados, Brasília, fevereiro de 2002. 
A Lei Pelé, o fim do passe e a modernização conservadora do futebol-negócio no Brasil: uma análise das percepções dos jogadores

RICHARDSON, R. J. Pesquisa Social: métodos e técnicas. São Paulo: Atlas, 1989.

RODRIGUES, F. X. F. O fim do passe e a modernização conservadora no futebol brasileiro (2001-2006). 2007. Tese (Doutorado em Sociologia) - PPGS/UFRGS, Porto Alegre, 2007.

RODRIGUES, F. X. F. A Lei Pelé e a modernização conservadora no futebol brasileiro: a concepção dos jogadores sobre os impactos do fim do passe no mercado futebolístico. CDROM 30 Encontro Anual da ANPOCS. São Paulo: ANPOCS, 2006.

RODRIGUES, F. X. F. A Sociologia do Trabalho e a Sociologia do Futebol: subsídios para uma análise da flexibilização das relações de trabalho no futebol brasileiro e dos os impactos do fim do passe (2001-2002). CD-ROM VII Congreso Argentino de Antropologia Social. Universidad de Córdoba. Villa Giardino, Córdoba, 25 a 28 de mayo 2004.

RODRIGUES, F. X. F. Formação do Jogador de Futebol no Sport Club Internacional (19972002). 2003. Dissertação (Mestrado em Sociologia) - PPGS/UFRGS, Porto Alegre, 2003.

Sindicato dos Atletas de Futebol. 1 ${ }^{\text {a }}$ Semana de Direito Desportivo, Canoas - RS, 2003.

SOUZA, Mário Marcos de. Quadro Negro. Zero Hora, Porto Alegre, 31 ag. 2002. Esporte, Bola Dividida, p.45.

SUPERVIELLE, Marcos e QUIÑONES, Mariela. La instalación de la flexibilidad en Uruguay. Sociologias, Porto Alegre, $n^{\circ}$ 4, jul/dez 2000.

TRIVIÑOS, A. N. S. Introdução à pesquisa em ciências sociais: a pesquisa qualitativa em educação. São Paulo: Atlas, 1987.

\section{LEIS E PROJETOS LEGISLATIVOS:}

MELO FILHO, Álvaro. Novo Ordenamento Jurídico-Desportivo. Fortaleza: ABC Fortaleza, 2000, p. $117 / 118$.

ALTHOFF, Geraldo. Senado Federal. Relatório final da CPI do futebol. Brasília. Dezembro de 2001.

Congresso Nacional. Lei nº 9.981. Brasília. 2000.

Congresso Nacional. Lei nº 9.615. Brasília. 1998.

Congresso Nacional. Lei nº 8.672. Brasília. 1993.

Congresso Nacional. Constituição Federal, Brasília. 1988.

Recebido em: 07/12/2013.

Aprovado em: 12/11/2014. 